\title{
PERLINDUNGAN HUKUM HAK CIPTA TERHADAP COVER VERSION LAGU DI YOUTUBE
}

\author{
Oleh : \\ Anak Agung Mirah Satria Dewi ${ }^{1}$
}

\begin{abstract}
Protection of copyright law against a cover version of a song on YouTube. Copyright protection only extends to the "expression" of the creator, and not to the "idea" or information derived from a work. This is what happens in cover songs, others have the freedom to express the same idea or reuse the information gained from the creation or work that is protected into the work afterward as long as the idea is expressed in a different way. The formulation of the problem in this research is 1. Does making cover versions of songs belonging to others and uploading to YouTube social media is a form of copyright infringement? and 2. What is the legal protection of the copyright holder for copyright infringement in the field of music and song in the form of commercial cover version?. The type of research used in this study is the type of normative legal research. The conclusion of the results of this research is in making cover versions of songs and uploading to YouTube social media in general do not violate the Copyright when the making an announcement is done by not violating the exclusive rights of copyright holder and legal protection against the copyright holder over copyright infringement in the field of music and songs in the form of commercialized version cover can be done through two ways, namely preventive efforts and repressive efforts.
\end{abstract}

\section{Keywords: Legal Protection, Copyright, Cover Version.}

Abstrak
Perlindungan hukum hak cipta terhadap cover version lagu di YouTube.
Perlindungan hak cipta hanya mencakup kepada "ekspresi" pencipta, dan
bukan kepada "ide" atau informasi yang didapat dari suatu ciptaan. Hal inilah
yang terjadi dalam kegiatan cover lagu, pihak lain memiliki kebebasan untuk
mengekspresikan ide yang sama atau menggunakan kembali informasi yang
diperoleh dari ciptaan atau karya yang dilindungi kedalam karya sesudahnya
selama ide tersebut diekspresikan dengan cara yang berbeda. Rumusan masalah
dalam penelitian ini adalah 1. Apakah membuat cover version lagu dan
mengunggah ke media sosial YouTube merupakan suatu bentuk pelanggaran hak
cipta? dan 2. Bagaimanakah perlindungan hukum terhadap pemegang hak cipta
atas pelanggaran hak cipta di bidang musik dan lagu dalam bentuk cover version
yang di komersilkan?. Jenis penelitian yang digunakan dalam penelitian ini
adalah jenis penelitian hukum normatif. Kesimpulan dari hasil penelitian ini yaitu
membuat cover version lagu dan mengunggah ke media sosial YouTube secara
umum tidak melanggar Hak Cipta apabila pembuatan dan pengumuman tersebut
dilakukan dengan tidak melanggar hak-hak eksklusif pemegang hak cipta dan

1 Program Studi Magister Ilmu Hukum Fakultas Hukum Universitas Udayana Denpasar, Bali. Email : anakagungmirahsatriadewi@yahoo.co.id 
perlindungan hukum terhadap pemegang hak cipta atas pelanggaran hak cipta di bidang musik dan lagu dalam bentuk cover version yang dikomersilkan dapat dilakukan melalui dua cara yaitu upaya preventif dan upaya represif.

\section{Kata kunci : Perlindungan Hukum, Hak Cipta, Versi Cover.}

\section{PENDAHULUAN}

Kekayaan intelektual merupakan kreativitas yang dihasilkan dari olah pikir manusia dalam rangka memenuhi kebutuhan dan kesejahteraan hidup manusia. $^{2} \quad$ Penemuan-penemuan (inventions) dan hasil karya cipta dan seni(artand literarywork) memberikan pengaruh yang besar terhadap kehidupan manusia. Ketika suatu hasil kreativitas manusia digunakan untuk tujuan komersial, muncullah pemikiran bahwa perlu adanya suatu bentuk penghargaan khusus terhadap karya intelektual seseorang dan hak yang muncul dari karya itu.

Pada dasarnya konsep Hak Kekayaan Intelektual merupakan bentuk penghargaan dari hasil kreativitas manusia, baik dalam bentuk penemuan-penemuan (inventions) maupun hasil karya cipta dan seni (art and literary work). ${ }^{3}$ Hak Kekayaan Intelektual (HKI) adalah hak kebendaan, hak atas sesuatu benda yang bersumber dari hasil kerja otak, hasil kerja rasio. ${ }^{4} \mathrm{Di}$ Indonesia sistem hukum HKI tersebut sudah muncul sejak Pemerintah Kolonial Hindia Belanda yaitu dengan

2 Kholis Roisah, 2015, Konsep Hukum Hak Kekayaan Intelektual, Setara Press, Malang, hlm. 2.

3 Ibid.

4 OK. Saidin, 2010, Aspek Hukum Hak Kekayaan Intelektual (Intellectual Property Rights), Rajawali Pers, Jakarta, hlm. 9. dikeluarkannya peraturan HKI yang meliputi Auteurswet 1912 Stb. 1912 No.600 bagi perlindungan hak cipta, Reglement Industriele Eigendom Kolonien Stb. 1912 No. 545 jo. Stb. 1913 No. 214 mengenai perlindungan hak merek, dan Octrooweit 1910 S.No. 33 yis S.11-33, S.22-54 mengenai perlindungan hak paten. ${ }^{5}$

Singkatan untuk Hak Kekayaan Intelektual (HKI) sudah tidak lagi dipergunakan dan berubah menjadi "KI". Mengenai perubahan istilah ini dapat diketahui melalui Pasal 25 Bagian Ketujuh Peraturan Presiden Republik Indonesia Nomor 44 Tahun 2015 tentang Kementerian Hukum Dan Hak Asasi Manusia Ayat 1"Direktorat Jenderal Kekayaan Intelektual berada di bawah dan bertanggung jawab kepada Menteri”, dalam Pasal tersebut digunakan istilah "Direktorat Jenderal Kekayaan Intelektual” bukan "Direktorat Jenderal Hak Kekayaan Intelektual". 6

Salah satu karya intelektual yang masuk ke dalam KI adalah hak cipta. ${ }^{7}$ Obyek yang dilindungi hak

5 Budi Santoso, 2008, Pengantar Hak Kekayaan Intelektual, Pustaka Magister, Semarang, hlm. 29.

6 Ni Ketut Supasti Dharmawan, dkk., 2016, Hak Kekayaan Intelektual (HKI), Deepublish, Yogyakarta, hlm. 13-14.

7 Bernad Nainggolan, 2011, Pemberdayaan Hukum Hak Cipta dan Lembaga Manajemen Kolektif, P.T Alumni, Bandung, hal. 9. 
cipta adalah ilmu pengetahuan, seni, dan sastra. Salah satu hak cipta di bidang seni adalah karya cipta lagu atau musik. Hampir semua orang di dunia menyukai lagu dan musik. Seiring dengan perkembangan ilmu pengetahuan dan teknologi, produkproduk yang berkaitan dengan ciptaan lagu atau musik pun telah berperan bagi peningkatan perekonomian masyarakat.

Lagu dan musik dalam kehidupan sehari-hari dipergunakan di berbagai kesempatan baik itu didengar, diperdengarkan, disiarkan, dipertunjukkan, serta disebarkan. Media yang digunakan bukan hanya televisi dan radio kini telah berkembang menggunakan handphone. Sebagian penggunaan lagu dan musik tersebut selau disertai dengan aktivitas ekonomi, sebagai contoh membeli lagu di handphone melalui aplikasi iTunes dan menonton video musik melalui aplikasi YouTube. Perkembangan teknologi terkait sarana untuk menikmati lagu dan musik tentu membawa dampak positif dan negatif. Dampak positifnya adalah masyarakat semakin mudah untuk menikmati musik, juga memudahkan pencipta dalam hal mempromosikan karyakaryanya, dampak negatifnya banyak orang yang justru menyalahgunakan teknologi untuk kepentingan pribadi seperti melakukan pembajakan, dan yang terbaru adalah mendapatkan keuntungan berupa uang dari membuat video cover yang diunggah ke YouTube. Fenomena pelanggaran terhadap Hak Cipta khususnya berupa pengumuman musik atau lagu saat ini seolah-olah berlangsung tanpa ada penyelesaian hukum yang berarti. Banyak pelaku usaha dalam kegiatan komersial usahanya menyiarkan musik atau lagu tanpa membayar royalti atau meminta izin dari penciptanya. Di Indonesia secara nasional hak cipta diatur dalam Undang-Undang Nomor 28 Tahun 2014 Tentang Hak Cipta.

Pengaturan tentang hak cipta secara Internasional dapat diketahui melalui Konvensi seperti : Berne Convention, Universal Copyright Convention serta TRIPs Agreement. ${ }^{8}$ Menurut Pasal 1 angka 1 UndangUndang No.28 Tahun 2014 tentang Hak Cipta, hak cipta adalah hak eksklusif pencipta yang timbul secara otomatis berdasarkan prinsip deklaratif setelah suatu ciptaan diwujudkan dalam bentuk nyata tanpa mengurangi pembatasan sesuai dengan ketentuan peraturan perundang-undangan. Melalui hak cipta, muncullah hak moral dan hak ekonomi. Hak moral diatur dalam Pasal 5 ayat (1) UU No. 28 Tahun 2014 tentang Hak Cipta yang meliputi hak untuk tetap mencantumkan atau tidak mencantumkan nama kreator pada salinan sehubungan dengan

8 Kadek Julia Mahadewi, Budaya Hukum Dalam Keberlakuan Undang-Undang Nomor 28 Tahun 2014 Tentang Hak Cipta Pada Pengerajin Perak Di Bali, Jurnal Magister Hukum Udayana, No. 2, Vol. 4, Edisi Juli 2015,https://ojs.unud.ac.id/index.php. jmhu/article/view/17341, diakses tanggal 14 November 2017. 
pemakaian ciptaannya untuk umum, menggunakan nama samarannya, sampai mempertahankan haknya dalam hal terjadi distorsi, pemotongan, modifikasi, dan hal-hal lain yang bersifat merugikan kehormatan atau reputasi sang kreator. Sedangkan hak ekonomi diatur dalam Pasal 8 UU No. 28 Tahun 2014 Tentang Hak Cipta meliputi penerbitan, penggandaan dalam segala bentuk, adaptasi, aransemen, transformasi, pendistribusian, hingga penyiaran atas ciptaannya.

Saat ini banyak sekali orang yang membuat cover version lagu milik orang lain kemudian merekamnya dan mengunggahnya ke media sosial YouTube. Cover version yang dibuat juga beragam, ada yang dibuat sederhana dan ada juga yang dibuat secara profesional. Istilah coverversion lagu bisa di artikan menyanyikan ulang lagu dari artis atau penyanyi terkenal dengan tidak mengubah lirik serta lagu aslinya. Perlindungan hak cipta hanya mencakup kepada "ekspresi”" pencipta, dan bukan kepada "ide" atau informasi yang didapat dari suatu ciptaan. ${ }^{9}$ Dalam kegiatan membuat cover version dari sebuah lagu, pihak lain memiliki kebebasan untuk mengekspresikan ide yang sama atau menggunakan kembali

9 Safina Meida Baqo dan Ranggalawe Suryasaladin, Permasalahan Hukum Hak Cipta pada Cover Version terhadap Lagu yang Dikomersialisasikan, Jurnal Hukum Universitas Indonesia, Mei 2016, http://www. lib.ui.ac.id/hasilcari?lokasi=lokal\&query= Safina + Meida + Baqo + , diakses tanggal 30 November 2017. informasi yang diperoleh dari ciptaan atau karya yang dilindungi kedalam karya sesudahnya selama ide tersebut diekspresikan dengan cara yang berbeda. Masalah muncul ketika cover version yang dibuat bersifat komersial sehingga muncullah sengketa mengenai pelanggaran hak cipta dari pihak yang berhak atas karya tersebut (Pencipta).

Berdasarkan latar belakang tersebut diatas, dalam penelitian ini dapat dirumuskan rumusan masalah sebagai berikut :

1. Apakah membuat cover version lagu dan mengunggah ke media sosial YouTube merupakan suatu bentuk pelanggaran hak cipta?

2. Bagaimanakah perlindungan hukum terhadap pemegang hak cipta atas pelanggaran hak cipta di bidang musik dan lagu dalam bentuk cover version yang dikomersilkan?

Penelitian ini merupakan karya ilmiah asli yang belum pernah diteliti sebelumnya. Adapun karya ilmiahyang terkait dengan karya ilmiah Penulis tentang Perlindungan Hukum Hak Cipta Terhadap Cover Version Lagu di YouTube yaitu karya ilmiah dari Safina Meida Baqo dan Ranggalawe Suryasaladin tahun 2016 dengan judul Permasalahan Hukum Hak Cipta pada Cover Version Terhadap Lagu Yang Dikomersialisasikan yang rumusan masalahnya adalah; 1. Bagaimanakah lisensi yang dibutuhkan agar cover version terhadap lagu untuk tujuan 
komersial tidak menjadi suatu pelanggaran Hak Cipta?; 2. Dalam hal terjadinya kegiatan cover terhadap suatu lagu untuk tujuan komersial, pihak-pihak mana saja yang berhak menerima dan memungut royalti dari pemanfaatan lagu yang terhadapnya dibuat cover version?. ${ }^{10}$ Kemudian karya ilmiah lainnya yang terkait yaitu dari Habi Kusno tahun 2016 dengan judul Perlindungan Hukum Hak Cipta Terhadap Pencipta Lagu Yang Diunduh Melalui Internet yang rumusan masalahnya adalah; 1. Bagaimana perlindungan hukum hak cipta terhadap pencipta lagu yang diunduh melalui internet?, 2. Upaya apa yang dilakukan dalam melindungi hak cipta pencipta lagu yang diunduh melalui internet ?.11 Jelas nampak perbedaan dari karya ilmiah tersebut dengan karya ilmiah yang dibuat oleh Penulis. Adapun perbedaan karya ilmiah ini dari karya ilmiah lainnya yaitu membahas tentang perlindungan hukum hak cipta di bidang musik dan lagu dalam bentuk cover version sedangkan dua karya ilmiah lainnya membahas mengenai permasalahan hukum hak cipta pada cover version lagu yang dikomersialisasikan dan perlindungan hukum terhadap pencipta lagu yang diunduh melalui internet.

10 Ibid.

11 Habi Kusno, Perlindungan Hukum Hak Cipta Terhadap Pencipta Lagu Yang Diunduh Melalui Internet, Jurnal Fakultas Hukum Universitas Lampung, No. 3, Vol. 10, Edisi Juli-September 2016,http://jurnal. fh.unila.ac.id/index.php/fiat/article/download/789/677, diakses tanggal 14 November 2017.
Tujuan dari penelitian ini adalah untuk memberikan gambaran yang jelas tentang bentuk pelanggaran hak cipta terhadap karya musik/lagu serta perlindungan hukum bagi pemegang hak cipta atas pelanggaran hak cipta dalam bentuk cover version yang dikomersilkan menurut UU No. 28 Tahun 2014 Tentang Hak Cipta.

\section{METODE PENELITIAN}

Metode penelitian hukum dalam bahasa Yunani disebut Methodos, Meta berarti diatas, sedangkan thodos berarti suatu jalan, suatu cara. Van Peursen menterjemahkan pengertian metode secara arfiah, mula-mula metode diartikan sebagai suatu jalan yang harus ditempuh menjadi penyelidikan dan penelitian berlangsung menurut suatu rencana tertentu. ${ }^{12}$ Penulisan karya ilmiah ini menggunakan jenis penelitian hukum normatif.

Penelitian hukum normatif artinya penelitian yang bertitik berat terhadap bahan hukum berupa aturan atau norma hukum positif dan menjadi bahan acuan utama dalam penelitian. ${ }^{13}$ Sedangkan menurut Peter Machmud Marzuki, penelitian hukum adalah suatu proses untuk menemukan aturan hukum, prinsip-prinsip hukum, maupun doktrin-doktrin hukum guns menjawab isu hukum yang

12 Jhony Ibrahim, 2006, Teori dan Metodeologi Penelitian Hukum Normatif, Bayu Publishing, Malang, hlm. 26.

13 Soerjono Soekanto dan Sri Mamuji, 2001, Penelitian Hukum Normatif Suatu Tinjauan Singkat, Raja Grafindo Persada, Jakarta, hlm. 51. 
dihadapi. ${ }^{14}$ Oleh karena itu, penelitian hukum merupakan suatu penelitian di dalam kerangka know-how di dalam hukum. ${ }^{15}$

Pendekatan yang digunakan dalam penelitian ini adalah pendekatan perundang-undangan (the statute approach). Pendekatan perundangundangan (the statute approach) dilakukan dengan cara mengkaji Undang-Undang No. 28 Tahun 2014 tentang Hak Cipta. Bahan hukum yang digunakan terdiri dari bahan hukum primer, bahan hukum sekunder, dan bahan hukum tersier.

III. HASIL DAN PEMBAHASAN

3.1 Konsep Cover Version dan Pelanggaran Hak Cipta pada Cover Version Menurut UU No. 28 Tahun 2014 tentang Hak Cipta

Cover version atau cover merupakan kegiatan membawakan/ mereproduksi ulang sebuah lagu/ musik milik orang lain yang sebelumnya pernah direkam dan dibawakan penyanyi atau artis lain. ${ }^{16}$ Cover juga dapat diartikan sebagai suatu pertunjukan oleh seseorang yang bukan pencipta dari karya musik/

14 Peter Machmud Marzuki, 2009, Penelitian Hukum, Kencana Prenada Media Group, Jakarta, hlm. 35.

15 Ibid, hlm. 41.

16 Lucky Setiawati, Apakah Menyanyikan Ulang Lagu Orang Lain Melanggar Hak Cipta, http://www.hukumonline.com/klinik/detail/ 1t506ec90e47d25/apakah-menyanyikanulang-lagu-milik-orang-lain-melanggar-hakcipta?, diakses pada tanggal 30 November 2017. lagu tersebut. ${ }^{17}$ Mencantumkan nama penyanyi asli dalam cover version yang dibuat untuk tujuan komersial (mendatangkan keuntungan ekonomi) tidaklah cukup untuk menghindari tuntutan hukum pemegang Hak Cipta. Seseorang harus memperoleh izin/ lisensi dari pencipta/pemegang hak cipta. $^{18}$ Berdasarkan definisi cover version diatas maka dapat diartikan bahwa cover version merupakan versi lain dari sebuah karya lagu/musik yang dibuat oleh orang lain yang bukan pencipta atau penyanyi lagu tersebut. Untuk mengunggahnya ke media sosial YouTube, seseorang bisa merekam lagu versi cover dalam bentuk video tanpa mengubah lagu aslinya.

Contoh kasus cover version yang terkenal adalah The National Music Publishers' Association vs. Fullscreen. Sekelompok perusahaan penerbit musik Amerika Serikat yang diwakili oleh the National Music Publishers' Association, menggugat salah satu perusahaan pemasok video terbesar ke YouTube yaitu Full screen ke pengadilan distrik di Manhattan, Amerika Serikat, pada 6 Agustus 2013 dengan alasan banyak dari videovideo yang diunggah Full screen terutama versi cover dari lagu-lagu hits milik artis-artis mereka dibuat tanpa izin publisher dan pencipta lagu serta tanpa membayar royalti sehingga melanggar hak cipta. Kasus ini diselesaikan melalui penyelesaian

$17 \quad$ Ibid

18 Ibid. 
sengketa diluar pengadilan dengan tercapainya kesepakatan yaitu kreator konten Full screen diharuskan untuk memiliki lisensi atas video musik mereka atau secara keseluruhan menghapus seluruh video cover yang hak ciptanya dipegang oleh pencipta maupun penerbit musik yang berada di bawah naungan the National Music Publishers' Association. ${ }^{19}$

Kasus kedua terjadi di Indonesia, cover version lagu Akad milik Payung Teduh oleh Hanin Dhiya. Cover lagu Akad yang dinyanyikan Hanin Dhiya dan diunggah ke media sosial YouTube ditonton sekitar 26 juta viewer bahkan mengalahkan versi aslinya yang ditonton oleh 17 juta viewer. Payung Teduh selaku pemilik asli lagu merasa keberatan dan mengatakan bahwa belum ada satu pun komunikasi atau izin untuk segala keperluan cover lagu Akad oleh Hanin Dhiya ke Payung Teduh. ${ }^{20}$ Payung Teduh mengatakan akan menunggu itikad baik dari Hanin Dhiya untuk datang dan mengkonfirmasi semuanya agar tidak perlu menempuh jalur hukum.

Hak cipta adalah bagian dari sekumpulan hak yang dinamakan hak atas kekayaan intelektual yang pengaturannya terdapat dalam ilmu hukum dan dinamakan hukum hak kekayaan intelektual. Yang dinamakan hukum KI ini yaitu suatu bidang hukum yang mengatur mengenai hak-hak yuridis dari karya-karya atau ciptaan-

19 Ibid.

20 M Faisal Reza Irfan, Laris Manis Cover Lagu “Akad", Bagaimana Hukumnya? diakses pada tanggal 30 November 2017. ciptaan hasil olah pikir manusia berkaitan dengan kepentingankepentingan yang bersifat ekonomi dan moral. ${ }^{21}$

Hak cipta atau copyright dalam TRIPs Agreement diatur pada Section 1 Copyright and Related Rights mulai dari Article 9 sampai dengan Article 14. Dalam Article 9 TRIPS Agreement diatur bahwa perlindungan copyright atau hak cipta mengacu dan mewajibkan negara-negara anggota mematuhi Berne Convention. ${ }^{22}$

PengaturanHakciptadiIndonesia terdapat di dalam Undang-Undang No. 28 Tahun 2014 tentang Hak Cipta, sementara itu secara Internasional pengaturan hak cipta terdapat dalam Berne Convention, UCC (Universal Copyright Convention), serta TRIPs Agreement. $^{23}$ Dalam UU No. 28 Tahun 2014 tentang Hak Cipta Pasal 1 angka 3 menyebutkan mengenai kriteria keaslian, bahwa ciptaan adalah hasil karya cipta di lapangan ilmu pengetahuan, seni dan sastra yang di hasilkan atas inspirasi, kemampuan, pikiran, imajinasi, kecerdasan, keterampilan, atau keahlian yang di ekspresikan dalam bentuk nyata. ${ }^{24}$ Kriteria keaslian dilihat dari apakah suatu ciptaan benar-benar merupakan hasil pemikiran dari si pencipta.

21 Suyud Margono, 2010, Hukum Hak Cipta Indonesia Teori Dan Analisis Harmonisasi Ketentuan World Trade Organization/WTOTRIPS Agreement, Ghalia Indonesia, Bogor, hlm. 21.

22 Ni Ketut Supasti Dharmawan, op.cit, hlm. 35.

23 Ibid, hlm. 36.

24 Ibid. 
Mengenai Pelanggaran hak cipta dan penyelesaian sengketa hak cipta diatur melalui Pasal 95 sampai dengan Pasal 120 UU No. 28 Tahun 2014 tentang Hak Cipta. Penyelesaian sengketa hak cipta menurut UU No. 28 Tahun 2014 tentang Hak Cipta dapat dilakukan melalui penyelesaian sengketa arbitrase (perdata) atau pengadilan (pidana). Untuk gugatan perdata diajukan ke pengadilan Niaga, sementara itu untuk tuntutan pidana menjadi kewenangan pengadilan Negeri. Tindak pidana berdasarkan ketentuan Pasal 120 UU No. 28 Tahun 2014 merupakan delik aduan. ${ }^{25}$

Teori yang digunakan sebagai pisau analisis dalam penelitian ini adalah teori hukumalam (theoryvan het natuursrecht) dari JohnLocke. Menurut teori hukum alam, bahwa pencipta memiliki hak moral dan hak ekonomi untuk menikmati hasil karyanya, termasuk keuntungan yang dihasilkan dari karya tersebut. Pencipta memiliki hak eksklusif atas karyanya karena pencipta telah menghibur masyarakat melalui ciptaannya, pencipta memiliki hak untuk mendapatkan imbalan yang sepadan. Hal ini berarti mempertahankan hukum alam dari individu untuk mengawasi karyakaryanya dan mendapat kompensasi yang adil atas sumbangannya kepada masyarakat. ${ }^{26}$

Apabila hak eksklusif dari pencipta tidak dilanggar, maka tidak

25 Ibid, hlm. 46.

26 Hendra Tanu Atmadja, 2004, Hak Cipta Musik atau Lagu, Hatta Internasional, Jakarta, hlm. 19. dapatdisebutsebagaisuatupelanggaran hak cipta. Beberapa hak eksklusif pemegang hak cipta adalah hak untuk membuat salinan atau reproduksi ciptaan dan menjual hasil salinan tersebut, mengimpor dan mengekspor ciptaan,menciptakankaryaturunanatau derivatif atas ciptaan, menampilkan atau memamerkan ciptaan di depan umum, menjual atau mengalihkan hak eksklusif tersebut kepada orang atau pihak lain. Yang dimaksud dengan "hak eksklusif" dalam hal ini adalah bahwa hanya pemegang hak cipta lah yang bebas melaksanakan hak cipta tersebut, sementara orang atau pihak lain dilarang melaksanakan hak cipta tersebut tanpa persetujuan pemegang hak cipta.

Perlindungan hak cipta terhadap karya lagu/musik berlaku selama hidup pencipta dan 70 tahun setelah pencipta meninggal dunia diatur dalam Pasal 58 UU No. 28 Tahun 2014. Perlindungan hak cipta dibagi menjadi dua, yaitu perlindungan terhadap hak moral (Pasal 5 ayat (1) UU No. 28 Tahun 2014) dan perlindungan terhadap hak ekonomi (Pasal 8 UU No. 28 Tahun 2014). Dalam kaitannya dengan cover version lagu/musik dapat dikatakan melanggar hak moral pencipta apabila tidak mencantumkan nama pencipta dari karya lagu/musik yang dibuat versi covernya, disebut melanggar hak ekonomi apabila menggunakannya untuk kepentingan komersial. UU No. 28 Tahun 2014 sendiri tidak mengenal istilah cover/cover version, yang dikenal adalah istilah salinan. 
Pembuatan dan penyebarluasan konten hak cipta melalui media teknologi informasi dan komunikasi yang bersifat tidak komersial, tidak dapat dikatakan sebagai suatu bentuk pelanggaran hak cipta (Pasal 43 huruf d UU No. 28 Tahun 2014).

\subsection{Perlindungan Hukum Terha-} dap Pemegang Hak Cipta atas Pelanggaran Hak Cipta di bidang Musik Dan Lagu dalam Bentuk Cover Version yang di Komersilkan

Perlindungan hukum terhadap hasil karya cipta menganut sistem perlindungan otomatis (automatically protection) artinya diperoleh oleh pencipta secara otomatis, tanpa melalui proses pencatatan terlebih dahulu pencipta secara otomatis sudah mendapat perlindungan hukum atas karya cipta nya saat karya tersebut sudah diwujudkan dalam bentuk karya cipta nyata (expression work). ${ }^{27}$

Konsep perlindungan otomatis dilandasi oleh salah satu prinsip dari Konvensi Berne (Berne Convention) yaitu Automatically Protection. Konsep perlindungan ini, artinya hak cipta boleh dicatatkan ataupun tidak. Menurut Pasal 64 ayat (2) UU No. 28 Tahun 2014 tentang Hak Cipta pencatatan suatu ciptaan bukan merupakan suatu kewajiban atau bersifat tidak mutlak. ${ }^{28}$

27 Ni Ketut Supasti Dharmawan, dkk, Op.cit, hlm.. 38-39.

28 Ibid, hlm. 39.
Meskipun menurut hukum hak cipta perlindungan hak cipta bersifat otomatis yang diperoleh oleh pencipta sejak ciptaan diwujudkan dalam bentuk nyata, dan tidak harus melalui proses pencatatan, namun apabila dilakukan pencatatan akan lebih baik dan lebih menguntungkan, karena dengan pencatatan, akan ada bukti formal adanya hak cipta jika tidak terbukti sebaliknya. Dengan adanya proses pencatatan jika terjadi peniruan atau penjiplakan karya cipta, si pencipta lebih mudah membuktikan haknya dan mengajukan tuntutan, karena ada bukti formal pencatatan. ${ }^{29}$

Hukum diciptakan sebagai suatu sarana atau instrumen untuk mengatur hak-hak dan kewajiban-kewajiban subyek hukum. Di samping itu, hukum juga berfungsi sebagai instrumen perlindungan bagi subyek hukum. Menurut Sudikno Mertokusumo hukum berfungsi sebagai perlindungan kepentingan manusia. Agar kepentingan manusia terlindungi, hukum harus dilaksanakan. ${ }^{30}$ Menurut Philipus M. Hadjon berpendapat bahwa perlindungan hukum adalah perlindungan harkat dan martabat, serta penegakan terhadap hak-hak asasi manusia yang dimiliki oleh subyek hukum berdasarkan ketentuan hukum dari kesewenangan. ${ }^{31}$

29 Ibid.

30 Sudikno Mertokusumo, 1993, Bab-Bab Tentang Penemuan Hukum, Citra Aditya Bakti, Bandung, hlm. 140.

31 Philipus M. Hadjon, 2007, Perlindungan Hukum Bagi Rakyat Indonesia, Bina Ilmu, Surabaya, hlm. 25. 
Penelitian ini mengkaji tentang perlindungan hukum yang diartikan sebagai suatu perlindungan terhadap subyek hukum dalamhal ini "pencipta". Hukum berfungsi untuk memberikan kejelasan hubungan antara hasil karya cipta dengan pencipta atau pemegang hak cipta atau orangyang menggunakan ciptaan. Adanya kejelasan hukum akan memberikan kemudahan pada penegakan hukum.

Berdasarkan Pasal 16 ayat 2 UU No. 28 Tahun 2014, menurut sifatnya hak cipta dianggap sebagai benda bergerak yang dapat beralih atau dialihkan baik melalui proses pewarisan, hibah, wakaf, wasiat, perjanjian tertulis atau sebab-sebab lain yang dibenarkan menurut ketentuan perundang-undangan. Hak cipta selain dapat beralih dan dialihkan juga dapat dilisensikan. ${ }^{32}$ Kata lisensi berasal dari kata Licentia yang berarti kebebasan atau ijin. Lisensi adalah izin yang diberikan oleh pemegang hak cipta atau pemegang hak terkait kepada pihak lain untuk mengumumkan dan/atau memperbanyak ciptaannya atau produk hak terkaitnya dengan persyaratan tertentu (Pasal 1 angka 14 UU No. 28 Tahun 2014). Objek lisensi bukan hanya hak cipta tetapi juga hak lain yang terkait dengan hak cipta. Hak yang dimaksud adalah hak cipta di bidang lagu atau musik, dimana lagu berkaitan dengan suara yang dapat direkam sehingga menimbulkan

32 Ni Ketut Supasti Dharmawan, dkk, Op.Cit, hlm. 40-41. hak di bidang rekaman. Kemudian apabila ciptaan itu disiarkan kepada masyarakat juga menimbulkan hak siar. Hak rekam dan hak siar merupakan hak yang menjadi ruang lingkup objek lisensi. ${ }^{33}$

Secara umum dalam Black's Law Dictionary, lisensi diartikan sebagai : a personal privilege to do some particular act or series of acts... atau the permission by competent authority to do an act which, without such permission would be illegal, a trespass, a tort, or otherwise would not allowable. ${ }^{34}$ Jadi berarti lisensi adalah suatu hak yang diberikan oleh orang yang berwenang terhadap ciptaan dalam bentuk izin kepada seseorang untuk melakukan satu atau serangkaian tindakan. Tanpa adanya izin tersebut maka tindakan atau perbuatan tersebut merupakan perbuatan melawan hukum. ${ }^{35}$

Khusus mengenai perlindungan hak pencipta lagu yang lagunya dibuat cover version dan dikomersilkan, perlu adanya perlindungan dan penegakan hukum yang efektif. Seperti teori yang diungkapkan oleh Roscoe Pound, law as a tool of social engineering ${ }^{36}$, hukum itu juga berfungsi sebagai sarana rekayasa sosial (sebuah jalan mencapai sebuah perubahan sosial).

33 Gatot Supramono, 2010, Hak Cipta Dan Aspek-Aspek Hukumnya, Rineka Cipta, Jakarta, hlm. 47.

34 Gunawan Widjaja, 2001, Seri Hukum Bisnis Lisensi, PT Raja Grafindo Persada, hlm. 3.

35 Ibid, hlm. 3.

36 Roscoe Pound, 2012, The Ideal Element in Law, Liberty Fund, Inc, hlm. 234. 
Dengan demikian, harus ada peraturan perundang-undangan yang dapat menciptakan perlindungan yang efektif terhadap hak-hak warga negara.

Mendasarkan pada teori tersebut, UU No. 28 Tahun 2014 tentang Hak Cita harus mengikuti perkembangan yang ada, termasuk perkembangan dunia teknologi. Terutama ketika perkembangan teknologi ini terkait erat dengan hak-hak warga negara. Adanya perlindungan hukum yang pasti serta penegakan hukum yang efektif, akan menjadi perangsang bagi para pencipta lagu maupun karya seni lainnya untuk semakin meningkatkan karyanya.

\section{KESIMPULAN}

Membuatcoverversion lagumilik orang lain dan mengunggah ke media sosial YouTube tidak merupakan suatu bentuk pelanggaran Hak Cipta apabila pembuatan dan pengumuman tersebut dilakukan dengan tidak melanggar hak-hak eksklusif pemegang hak cipta. Menurut Pasal 43 huruf d UU Hak Cipta "perbuatan yang tidak dianggap sebagai pelanggaran hak cipta meliputi: pembuatan dan penyebarluasan konten hak cipta melalui media teknologi informasi dan komunikasi yang bersifat tidak komersial dan/ atau menguntungkan pencipta atau pihak terkait, atau pencipta tersebut menyatakan tidak keberatan atas pembuatan atau penyebarluasan tersebut". Apabila pembuatan dan pengumuman cover version tersebut dilakukan dengan tanpa hak dan untuk mencari keuntungan atau bertujuan komersial, maka pembuatan dan pengumuman cover version tersebut merupakan pelanggaran hak cipta.

Perlindungan hukum terhadap pemegang hak cipta atas pelanggaran hak cipta di bidang musik dan lagu dalam bentuk cover version yang dikomersilkan dapat dilakukan melalui dua cara yaitu upaya preventif dan upaya represif. Upaya preventif yaitu dengan melakukan pencatatan ciptaan seperti diatur dalam Pasal 66-67 UU Hak Cipta. Ciptaan sudah dilindungi sejak ciptaan itu lahir sehingga tidak wajib untuk dicatatkan tetapi fungsi pencatatan hak cipta dimaksudkan untuk memudahkan pembuktian dalam hal terjadi sengketa mengenai hak cipta. Upaya represif yaitu melalui penyelesaian sengketa arbitrase atau pengadilan (Pasal 95 Ayat 1 UU No. 28 Tahun 2014). Gugatan perdata diajukan ke Pengadilan Niaga dan tuntutan pidana diajukan ke Pengadilan Negeri.

\section{DAFTAR PUSTAKA}

\section{BUKU}

Ibrahim, J. (2006). Teori dan Metodeologi Penelitian Hukum Normatif. Bayumedia Publishing, Malang.

Marzuki, P. (2009). Mahmud. Penelitian Hukum. Kencana Prenada Media Group. Jakarta. 
Margono, S. (2010). Hukum hak cipta Indonesia: teori dan analisis harmonisasi ketentuan World TradeOrganization/WTO-TRIPs agreement. Ghalia Indonesia. Bogor.

Mertokusumo, M. S., \& Pitlo, A. (1993). Bab-bab tentang penemuan hukum. Citra Aditya Bakti. Bandung

Nainggolan, B. (2011). Pemberdayaan hukum hak cipta lagu atau musik melalui fungsi lembaga manajemen kolektif. Alumni. Bandung.

Pound, R. (2012). The ideal element in law. Liberty Fund.

Roisah, K. (2015). Konsep hukum hak kekayaan intelektual (HKI): sejarah, pengertian, dan filosofi pengakuan HKI dari masa ke masa. Setara Press. Malang.

Saidin, O. K. (1995). Aspek Hukum Hak Kekayaan Intelektual (Intellectual Property Rights). Rajawali Pers, Jakarta.

Santoso, B. (2008). Pengantar HKI (Hak Kekayaan Intelektual). Pustaka Magister: Semarang.

Soekanto, S., \& Mamudji, S. (2001). Penelitianhukumnormatif: Suatu tinjauan singkat. RajaGrafindo Persada. Jakarta.

Supasti Dharmawan, Ni Ketut, dkk., (2016). Buku Ajar HakKekayaan Intelektual (HKI). Deepublish. Yogyakarta.

Supramono, G. (2010). Hak Cipta dan Aspek-Aspek Hukumnya. Jakarta: Rineka Cipta.
Atmadja, H. T. (2004). Perlindungan hak cipta musik atau lagu. Hatta Internasional.

Gunawan, W. (2001). Seri Hukum Bisnis Lisensi. RajaGrafindo Persada, Jakarta.

\section{ARTIKEL JURNAL}

Kusno, H. (2016). Perlindungan Hukum Hak Cipta Terhadap Pencipta Lagu Yang Diunduh Melalui Internet. Fiat Justisia, $10(3)$

Mahadewi, K. (2015). BUDAYA HUKUM DALAM KEBERLAKUAN UNDANG-UNDANG NOMOR 28 TAHUN 2014 TENTANG HAK CIPTA PADA PENGRAJIN PERAK DI BALI. JurnalMagister Hukum Udayana (Udayana Master Law Journal), 4(2). doi:10.24843/JMHU.2015. v04.i02.p01

Safina Meida Baqo dan Ranggalawe Suryasaladin. (2014). Permasalahan Hukum Hak Cipta pada Cover Version terhadap Lagu yang Dikomersialisasikan, Jurnal Hukum Universitas Indonesia, http://www.lib.ui.ac.id/ naskahringkas/2016-05/S57258Safina\%20Meida\%20Baqo.

\section{PERATURAN}

\section{PERUNDANG-UNDANGAN}

Undang-Undang Republik Indonesia Nomor 28 Tahun 2014 Tentang Hak Cipta, Lembaran Negara Republik Indonesia Tahun 
2014 Nomor 266, Tambahan Lembaran Negara Republik Indonesia Nomor 5599.

\section{INTERNET}

Lucky Setiawati, Apakah Menyanyikan Ulang Lagu Orang Lain Melanggar Hak Cipta, http://www.hukumonline.com/klinik/ detail/lt506ec90e47d25/apakahmenyanyikan-ulang-lagu-milik-oranglain-melanggar-hak-cipta?, diakses pada tanggal 30 November 2017.

M Faisal Reza Irfan, Laris Manis Cover Lagu "Akad", Bagaimana Hukumnya?, https://tirto.id/larismanis-cover-lagu-akad-bagaimanahukumnya-cxgV, diakses pada tanggal 30 November 2017. 